Jurnal DinamikA

Volume 1 No. 2 (2020)

E-ISSN: $2723-1410$

Website: https://jurnal.iainsalatiga.ac.id/index.php/dinamika/index

\title{
Self-Destructive Behavior Analysis of Hannah Baker in The Thirteen Reasons Why Novel
}

\author{
Jeantriani Febrita ${ }^{1}$, Eka Margianti Sagimin ${ }^{2}$ \\ ${ }^{1,2}$ English Department, Universitas Pamulang, Tangerang Selatan, Banten \\ Email: jeantriani@gmail.com ${ }^{1}, \underline{\text { ekamargy@yahoo.com }}{ }^{2}$
}

\begin{abstract}
This study investigates Self-Destructive Behavior of Hannah Baker in Thirteen Reasons Why novel, conducted in qualitative approach analysis of self-destructive behavior of the main character and what reasons or the causes of it through the narratives in the Thirteen Reasons Why novel. The goal of the study is to analyze how self-destructive behavior impacted the main character, Hannah Baker which is described using the theory of Self-Destructive Behavior and Defense Mechanisms by Sigmund Freud (1966). The result of this study shows that Hannah Baker developed the self-destructive behavior as a defense mechanisms from herself that triggered by trauma from the past. It started with the non-suicidal self-destructive behavior but soon turns into the suicidal self-destructive behavior. This study also shows how a suicide can really be an impact of the behavior that happens in the novel resulted from a non-suicidal self-destructive behavior that is not handled well, and all the mistreatments that the main character felt which produce the desire for ending her life.
\end{abstract}

Keywords: Self-Defense Mechanism, Self-Destructive Behavior, Sigmund Freud, Suicide, Thirteen Reasons Why.

\begin{abstract}
Abstrak
Penelitian ini menganalisa Self-Destructive Behavior dari Hannah Baker dalam novel Thirteen Reason Why, dilakukan dengan metode kualitatif ini menganalisa tentang self-destructive behavior serta apa alasan atau penyebab sang pemeran utama melakukan itu menurut novel Thirteen Reasons Why. Tujuan dari penelitian ini adalah untuk menganalisis bagaimana self-destructive behavior berdampak pada karakter utama, Hannah Baker menggunakan teori Self-Destructive Behavior dan Defense Mechanisms oleh Sigmund Freud (1966). Hasil penelitian ini menunjukkan bahwa self-destructive behavior Hannah Baker timbul sebagai bentuk pertahanan diri akibat dari trauma yang dialami sebelumnya. Dimulai dengan non-suicidal self-destructive behavior lalu berubah menjadi suicidal self-destructive behavior. Penelitian ini juga menunjukkan bagaimana bunuh diri dapat menjadi dampak buruk dari perilaku nonsuicidal self-destructive behavior yang tidak ditangani dengan baik, dan semua perlakuan buruk yang dirasakan oleh karakter utama dapat menghasilkan keinginan untuk mengakhiri hidupnya.
\end{abstract}

Kata Kunci: Bentuk Pertahanan Diri, Bunuh Diri, Perilaku Merusak Diri Sendiri, Sigmund Freud, Thirteen Reasons Why. 


\section{Introduction}

Self-destructive behavior mostly happened to anyone in society, especially among teenager. Teenagers are still sensitive since it is the phase where they are seeking for their passion and trueself, as well as going through puberty. As Wolde (2014) stated, self-destructive behaviors are a set of abnormal behaviors that lead to physical injury or damage to one's own body. This abnormal and dangerous behavior results in physical injury or even death. People tend to have this selfdestructive behavior from the stress and pressure they had at school, environment, and the people in it. The reason of self-destructive behavior is various, most of them are depression. Those who cannot bear the stress and depression usually blame and even harm themselves in order to feel better as the result of the self-destructive behavior.

This behavior causing a bad impact to human's body, not only physically but also mentally. Physically, self-destructive behavior could make someone do dangerous things to harm themselves. Mentally, it could drain someone's energy and leave them stressed out as well as depressed. Numerous studies have found that self-destructive behaviors can be expressed generally in different self-harming behaviors such as self-mutilation, smoking, drinking alcohol, using drugs, participating in violent groups, intentional injuries, and improper ways of eating. And among those self-mutilation is the most common form. (Nock, 2010; Fox \& Hawton 2005). Studies also found that the most extreme cases of self-destructive behaviors are suicide.

Self-destructive behavior also occurs in the real life, public figure in particular is the example because they live a life full of pressure. One of them is the famous female singer from America, Demi Lovato, have to deal with depression ever since she got bullied because of her body at school at the age of 8 . It made her developed an eating-disorder and decided to go home-schooled. Being famous at the young age did not do any difference for her, and at the age of 11 she started selfcutting because of the bully and hate she received. This unfortunately leads her to do things, like drinking and using (drugs) as self-medicating to numb the pain. However, she seeks for help and treatment immediately, she went to rehab and even though she had been living in a sober-living facility in LA, she stated that she still working hard on herself and still need space and time to heal. People with self-destructive behavior usually needs some times alone but still under control of someone professional, because they tend to be careless. When they did not find any help, it could 
Jurnal DinamikA

Volume 1 No. 2 (2020)

E-ISSN: $2723-1410$

Website: https://jurnal.iainsalatiga.ac.id/index.php/dinamika/index

lead them to be a reckless person and suicide would be a possible option for them to numb their pain.

Unfortunately, there are some cases in Indonesia where self-destructive behavior became a trend, especially self-mutilation or self-cutting. As Galuh Ratnatika wrote, at the beginning of September 2018, there were about 56 Junior High School students in Surabaya had the habit of cutting their hands. After being investigated, those students had suffered from depression. Not long after, in mid-September, around 50 Junior High School students in Pekanbaru were reported to cut their hands. Surprisingly, from the result of the assessment carried out by the school, it was known that they were cutting hands to follow the trends on social media. This clearly must be a concern of the schools, because it does not rule out the possibility that these problems also occur in other schools. The pressure or problems at home, and wrong association can cause students to take the wrong action to solve their problems.

There are a lot of authors who discussed about self-destructive behavior issues into story in literature as a reflection of the social condition and problem that happens to the human life, and Thirteen Reasons Why by Jay Asher is one of the examples. It is the story of a young high school student, Hannah Baker that sends cassette tapes and explains to everyone who, in her opinion, is responsible for her suicide. Hannah became a victim of bully in her school that traumatizes her and makes her lost confidences. That makes her has self-destructive behavior, closed herself and pushed people away. She was asking for help from the school advisor, who eventually led her to the decision to end her life after she had prepared the thirteen cassettes.

Thirteen Reasons Why is one of the novels that bravely exposed the devastating topics and experiences teenagers are faced. The facts that Hannah Baker's characters portrayed the selfdestructive behavior in Thirteen Reasons Why novel seems to be similar with many people in the world experienced today makes the writer interested in analyzing the problem better. This study focuses on the term of Self-destructive behavior, how it described in the character and the causes of it towards the main character. 


\section{Self-Destructive Behavior And Defense Mechanism}

When people experience difficulties, they have different ways of handling their pain. These different ways of dealing with pain are called defense mechanisms. Defense mechanisms can be healthy or unhealthy depending on the circumstances and how much a person uses them. The unhealthy defense mechanism often assert the existence of an aggressive instinct or Freud prefer to call it 'destructive behavior' or 'death instinct' (Freud, 1966). Thus do not rule out the possibility of a person to have a self-destructive behavior because they cannot handle the pain.

The term self-destructive behavior is defined as self-induced, deliberate, harmful, injurious, or aggressive behavior toward one's own body, exhibiting suicidal ideation and/or behavior, but without a conscious intent to die (Wood, 1997). Perhaps in Freudian theory was known as Thanatos or the force of death and destructions. According to Freud (1961), people yearn for death in order to achieve real peace since only death can free them from all of the life's struggles. Death naturally exists in almost every person's subconscious as it is an irresistible instinctive power in human beings consciousness.

Thanatos simply emerges when a person is significantly desperate for whatever reason, and makes them feel a strong urge to die. Nevertheless, Thanatos can not only lead to self-destruction but also to injuries and death of other people (Freud, 1961). Thus, the difference between selfdestructive behavior, such as self-mutilation, and suicidal attempt can cause confusion but the distinctive characteristics of the two actions can be separated by the motive of the person. Moreover, a person with self-destructive thoughts only harm themselves when they feel so stuck in order to manage the stress. Meanwhile a person with suicidal attempt harm themselves with the thought of ending their life.

Further, Nock (2010) also describes the major causes that lead to self-destructive behaviors in his theory as "genetic predisposition for high emotional cognitive reactivity, childhood abuse and mistreatments, family hostility and criticism". Individuals who have self-destructive behavior usually are unwilling or unable to ask for help about their problems, emotional problems, unhealthy life style such as eating disorder or alcohol addiction or other substance abuse. In addition, these individuals externally can look normal and take care of others around them but 
Jurnal DinamikA

Volume 1 No. 2 (2020)

E-ISSN: $2723-1410$

Website: https://jurnal.iainsalatiga.ac.id/index.php/dinamika/index

they are internally very sensitive and have a low self-esteem, having a lower opinion of themselves and ashamed of their self-destructive behaviors. Also have negative feeling about normal thought, feelings and emotions such as sexual desire or anger, and they have a feeling of insecure, guilt and shame for experiencing such feelings and emotions (Rissanen, 2011). The feeling of insecure, guilt and shame will lead to self-hate and self-punishment for feelings they had.

Insecure attachment patterns are also associated with self-destructive behaviors, suicidal ideation and depressive symptoms. Adam, Sheldon-Keller and West (1996) propose that suicidal tendencies arise from attachment patterns established in infancy and seem to be particularly associated with preoccupied attachment patterns. Experience with insecure attachments causes teenagers to develop negative self-representations that lead to low self-esteem, hopelessness, and difficulty regulating emotions and sustaining interpersonal relationships, which can promote the development of psychological maladaptation, including self-destructive behaviors.

\section{Death And Life Instinct (Thanatos And Eros)}

Having self-destructive ideation or Thanatos instinct during difficult times must be crossing teenager's mind, especially those who thought they have failed to achieve something, and they thought others was mocking them for failing. As Starr (2004) mention, people who had a selfdestructive behavior, harm themselves for various reasons: to run away from feelings, to feel pain outside rather than on the inside, to cope with feelings, to express anger towards the self, to feel alive, to turnoff emotions, to gain control, to express to others that they need help and to manipulate situations and people. They prefer harming themselves in ways such as, cutting or mutilating, because they thought the scars it left was way better than the scars on the inside that they felt.

According to Sell (2005), self-destruction accomplishes two things. First, it allows individuals a choice as to when they want to use physical pain to replace the emotional pain they are experiencing. Second, the act of self-mutilation as a diversion from the emotional pain they believe they cannot handle and the act repeated. Moreover, in Freud's view, the compulsion to repeat was something that would seem more primitive, more elementary, more instinctual than the pleasure 
principle which it overrides. He further proposed that the death instincts were an extension of that compulsion wherein all living organisms have an instinctive pressure toward death which stands in stark contrast to the instinct to survive, procreate, and satisfy desires. This pattern of selfdestruction can be just as addictive as smoking, over eating and drinking alcohol in excess as Gilbert (2010) stated, individuals who self-harm may also achieve temporary calming due to release of endorphins, which produces a sense of relief.

In opposite of Thanatos, stands the self-preserving instinct Eros. Sometimes referred to as sexual instincts, the life instincts are those which deal with basic survival, pleasure, and reproduction. These instincts are essential for sustaining the life of the individual, also include such things as thirst, hunger, and pain avoidance. In his early psychoanalytic theory, Freud proposed that Eros was opposed by forces of the ego, the organized, realistic part of a person's psyche which mediates between desires. In this later views, he maintained that life instincts (Eros) were opposed by the self-destructive death instincts, known as Thanatos.

At first sight, we may see Eros as something clearly positive whereas Thanatos as something inevitably negative. Yet, the two are closely intertwined and one can even turn into another. For instance, we would consider the impulse of hunger to be an Eros instinct. However, if we were to kill something in order to ease that hunger, it would mean destruction of that which would be eaten.

\section{Individual And Social Factors Of Self-Destructive Behavior}

A person's thoughts of themselves and how they want others to see them as, can be one of the self-destructive behavior's factor. As Gilbert (2010) said, this individual factor which can be a cause for behavioral problems, such as self-destructive problem, can be genetic factors for high emotional reactivity, emotional and cognitive problems or mental illness, poor distress tolerance, self-criticism, shame and social comparison. However, a person can also protect themselves from the thoughts by using defense mechanisms to operate an unconscious level help ward off unpleasant feelings or make good things feel better for the individual.

Whereas, Lee (2010) stated that social factors contributed to self-destructive behavior, also differs according to family interaction, individualism, traditional values, socio-economic factors, 
Jurnal DinamikA

Volume 1 No. 2 (2020)

E-ISSN: $2723-1410$

Website: https://jurnal.iainsalatiga.ac.id/index.php/dinamika/index

and social-political situation. A traumatic event encountered by individual also becoming one of the factors for one's self-destructive behavior.

Many studies showed self-destructive behaviors are associated with past mistreatment of people at a young age and/or current life complication in one or multiple undesired experiences such as family problem or interpersonal conflict (Wolde, 2014). From a different perspective, one may argue that having suicide ideation at difficult times is quite normal. However, as suicidal ideation is a sign of later suicidal behavior, the seriousness of suicide ideation should not be underestimated.

\section{Types Of Self-Destruction And Defense Mechanism}

Self-destructive or self-harming behavior seems completely illogical and typical of madness. However, it is a negative impulse that people carry within themselves to a greater or lesser extent. Far too many people set themselves up for defeat as they are unwilling to acknowledge the destructive side of their being. Utilizing various psychological defense mechanisms such people do their best to stay ignorant to their faults and weaknesses. In so doing these elements of their personality are relegated to their unconscious and make up the realm of the psyche Jung called the shadow. The shadow is prone to psychological projection, whereby a person attribute to others all their evil and inferior qualities that they do not want to admit are in themselves.

Sigmund Freud, who popularized the term in the mid-1890s, believed projection to be a defense mechanism used to avoid the anxiety that is provoked when one is forced to face up to their faults, weaknesses, and destructive tendencies. Originally conceived by Sigmund Freud, much of the development of defense mechanisms was done by his daughter, Anna Freud, there are;

a) Repression: Burying a painful feeling or thought from your awareness though it may resurface in symbolic form. Sometimes considered a basis of other defense mechanisms.

b) Denial: Not accepting reality because it is too painful.

c) Regression: Reverting to an older, less mature way of handling stresses and feelings. 
d) Projection: Attributing your own unacceptable thoughts or feelings to someone or something else.

e) Splitting: Everything in the world is seen as all good or all bad with nothing in between.

f) Isolation of affect: Attempting to avoid a painful thought or feeling by objectifying and emotionally detaching oneself from the feeling.

g) Displacement: Channeling a feeling or thought from its actual source to something or someone else.

h) Reaction: Formation Adopting beliefs, attitudes, and feelings contrary to what you really believe.

i) Rationalization: Justifying one's behaviors and motivations by substituting "good", acceptable reasons for these real motivations.

j) Altruism: Handling your own pain by helping others.

k) Humor: Focusing on funny aspects of a painful situation.

1) Sublimation:Redirecting unacceptable, instinctual drives into personally and socially acceptable channels.

m) Suppression: The effort to hide and control unacceptable thoughts or feelings.

n) Undoing: Trying to reverse or "undo" a thought or feeling by performing an action that signifies an opposite feeling than your original thought or feeling

Other than that habits, there are four traits or symptoms of Self-destructive behavior:

a) Driving others away or scared to mess up relationship (isolation).

b) Self-punishment in response to personal failure (self-hatred or loathing).

c) Feeling of self-hatred.

d) Losing interest in things that once brought happiness. 
Jurnal DinamikA

Volume 1 No. 2 (2020)

E-ISSN: $2723-1410$

Website: https://jurnal.iainsalatiga.ac.id/index.php/dinamika/index

It is true that those who have these traits or habits have difficulty with their self-esteem. It is as if habits were enough to make certain self-defeating behaviors persist. Initially, the behavior might have been motivated by some obscure fear, but then habit itself took over. Habit makes life easier, but not every habit (Neuman, 2017). However, it seems that people are committed in one way or another to doing the things they have always done in the way they have always done them, whether those behaviors make sense or not.

\section{Research Method}

In analyzing this novel, the writer uses the qualitative approach. Qualitative approach is used because the data source was taken from many books, journals, articles, and essays. Creswell (1994) states that qualitative research is an inquiry process of understanding based on distinct methodology traditions of inquiry that explore a social or human problem. It means that qualitative methods are ways to collecting data from different sources to get an explanation and to support writer ideas.

It can be concluded that qualitative approach provides more emphasis on interpretation and providing consumers with complete view, looking at contexts, environmental immersions and depth of understanding of concepts analysis in textual descriptions.

\section{Finding And Discussion}

There are two parts that are analyzed in this chapter. The first part is the dimension of Selfdestructive Behavior and how the character associated with it. The second part is the trigger of an event that makes the main character developed Self-destructive Behavior in the novel. The writer selected the data based on textual paragraphs in the novel.

\section{Self-Destructive Behavior Of Hannah}

Based on Freud's (1961) theory, when individuals lead others to believe they intend to die from their behavior means that the person have a non-suicidal self-destructive behavior. In the theory, there are three primary types of non-suicidal self-destructive behavior and Hannah's 
behavior that leads other to believe that she intends to die is one of them, which called suicide treat or gesture.

Harming others and self-pity are also the habits of self-destructive behavior person. Sometimes because they had lost a lot of self-confidences and thought they were never be enough they will end up blaming and harming others to make them feel a lot better. But after that they will think that they should not harming others because it was them the one to blame and turn into a whole self-pity state.

\section{Datum 1 (Page 7, Line 7-9)}

"I hope you are ready; because I'm about to tell you the story of my life. More specifically; why my life ended. And if you're listening to these tapes, you're one of the reasons why."

Being the self-destructive person, Hannah refuse to tell the truth when she was alive because she rather harming them back when she was not there anymore so that they did not able to blame her for that. She gets back to them by harming them mentally, so they can feel what she felt before she killed herself. From the first chapter, Hannah was already playing with her listener's emotions just by saying things such as those quotation above. Making the listener of her tapes confused, anxious and bruised their mental state.

When one was being difficult to be help, or even do not want to be well and keep on acting the same way. It is easier for them to act like everything was okay and so they refusing anyone who want to help them.

\section{Datum 2 (Page 148, Line 14-15)}

"You don't need to watch out for me, Clay."

The quotation above is the evidence of Hannah pushing people away, especially Clay. It is clear that she purposely pushed Clay away and refused to be helped by him, when she can easily talk to him about the mistreatment she received at school.

Datum 3 (Page 166, Line 5)

"I admit, during class discussions I didn't open up much."

This time Hannah admit about her did not open up much even though at that time the class was talking about the problem she mentioned anonymously. In the story, Hannah was anonymously writing a topic about suicide into the Peer Communication class in hope everyone 
Jurnal DinamikA

Volume 1 No. 2 (2020)

E-ISSN: $2723-1410$

Website: https://jurnal.iainsalatiga.ac.id/index.php/dinamika/index

would notice that it was her wrote the topic. But how can everyone know if she did not even say a word when the topic was brought up.

\section{The Causes Of Hannah's Self-Destructive Behavior}

Hannah is a character who tries to adapt to her new surroundings especially people around her and why they do what they do. There are a lot of misunderstanding that turns into her receiving mistreatment and developed a self-destructive behavior. These are some of the reasons or causes of Hannah's Self-Destructive Behavior:

\section{Datum 1 (Page 13, Line 16)}

"Betrayal. It's one of the worst feelings."

According to Hannah in the story the feeling of betrayal was the worst feeling, because she felt it so many times and it was as if this feeling of betrayal was the trigger of her self-destructive behavior. She started to have a lot of distrust to people around her, and decided to shut herself off of others. She was afraid of being betrayed, yet she was naïve and ended up trusting the wrong people.

\section{Datum 2 (Page 28, Line 24)}

“Wait. Stop. Don't rewind. There's no need to go back because you didn't miss a thing. Let me repeat myself. That...is...all...that...happened. Why, did you hear something else?" A shiver races up my spine. Yes. I did. We all did.”

The lines above depict how in the beginning of the chapter Hannah was already hinting that there was misunderstanding or negative rumors about her. In the beginning of the chapter Hannah told or rather clarified to the listener of the tapes of all the misunderstanding or negative rumors about her. She told the listener from her point of view that was never even heard before, because people around her choose to believe the rumors rather than asked her about it themselves. The line 'Yes. I did. We all did.' was the listener's point of view, which confirmed the negative rumors about Hannah. This chapter tells how the negative rumors about Hannah started and makes a snowball effect on her reputation.

Datum 3 (Page 169, Line 11-15) 
"When that happened, my parents became distant. There was suddenly a lot for them to think about. A lot of pressure to make ends meet. I mean, they talked to me, but not like before. When I cut my hair, my mom didn't even notice."

The last reasons of Hannah's self-destructive behaviors are lack of parent's love and/or attention. This chapter shows that ever since they moved out from their old city, her parents became distant and no longer pay attention to her unlike before. The line "When I cut my hair, my mom didn't even notice." shows how she needed her parent's attention and love just like they used to before, yet because of what happened to her family before makes her parents have to pay attention to other things more than to her. The lack of love and attention her parents gave her was triggering her own negative thoughts, making her believe that there would be no one that want her to fight and survive her own battle.

After analyzing the Thirteen Reasons Why novel, there was found some data evidences about the cause of Hannah's self-destructive behavior. These data prove that Hannah has developed selfdestructive behavior and the reasons or the causes of Hannah's self-destructive behavior could also happen in real life.

\section{Conclusion}

Based on the findings and analysis found in chapter four, this chapter present the conclusion from the answers of the statements of problem. This chapter also gives some suggestions to build a better understanding of self-destructive behavior using Sigmund Freud theory.

On the finding and analysis entitled Self Destructive Behavior Analysis of Hannah Baker in the "Thirteen Reasons Why" Novel presents self-destructive behavior through the main character Hannah Baker. Hannah has some personalities that reflect a self-destructive behavior person. It showed on her daily life that Hannah performs a repetition action in her personality. In this study there are two important points discussed. First, the analysis about Hannah's self-destructive behavior which includes a few characteristics of it such as leading others to believe she intend to die, housing self-defeating mindsets, forced incompetence, failing to take action to remedy issues, harming others and self-pity, social suicide, refusing to be helped, and unnecessary self-sacrifice. The second data is about the triggers of self-destructive behavior, in Hannah's case concerns on 
Jurnal DinamikA

Volume 1 No. 2 (2020)

E-ISSN: $2723-1410$

Website: https://jurnal.iainsalatiga.ac.id/index.php/dinamika/index

several points such as betrayal, misunderstanding/negative rumors about her, losing safety haven, losing reason to hold on, losing parent's love/attention.

In addition, every data collected about self-destructive behavior are analyzed using Sigmund Freud theory. Hannah performs her self-destructive behavior analyzed based on the textual evidence which structures of chapter, page, line, self-destructive behavior and the cause. At the end of the study, it can be concluded that someone could have a self-destructive behavior which was the non-suicidal behavior or suicidal behavior, and some people still careless about it and tend to think about them as an attention seeker instead of actually listen to them and help.

\section{References}

Abrams, M. (1982). A Glosary of Literary Terms. New York: Earl Mc Peek.

Adam, K., Keller, A. S., \& West, M. (1996). Attachment organization and history of suicidal behavior in clinical adolescents. Journal of Consulting and Clinical Psychology, 264-272.

Asher, J. (2016). Thirteen Reasons Why. United Kingdom: Razorbill.

Bernardo, K. (2011). Types of Characters in Fiction. Vancouver, Canada: Colin Welch Teaching Resources.

Cahyono, A. (2017). Psychoanalysis of Personality Disorder of Main Character in 'Veronika Decides To Die' Novel by Paulo Coelho. Tangerang Selatan: Universitas Pamulang.

Cerdorian, K. (2005). The Needs of Adolescent Girls who Self-Harm. Journal of Psychosocial Nursing and Mental Health Services, 41.

Chan, W., Law, C. K., Liu, K., Wong, P., Law, Y. W., \& Yip, P. (2009). Suicidality in Chinese adolescents in Hong Kong: the role of family and cultural influences. Pokfulam, Hong Kong: University of Hong Kong.

Collis, E. (2012, January 5). Demi Lovato Exclusive Interview. Retrieved from Seventeen: www.seventeen.com 
Creswell, J. W. (2014). Research Design Qualitative, Quantitative, and Mixed Methods Approaches. California: Sage Publications, Inc.

Fox, C., \& Hawton, K. (2005). Deliberate Self-Harm in Adolescence. London: Jessica Kingsley Publishers.

Gilbert, P., McEwan, K., Irons, C., Bhundia, R., Christie, R., Broomhead, C., \& Rockliff, H. (2010). Self-harm in a mixed clinical population: The roles of self-criticism, shame, and social rank. British Journal Of Clinical Psychology, 563-576.

Hawton, K., Fagg, J., Simkin, S., Bale , E., \& Bond, A. (2000). Deliberate Self-Harm in Adolescents in Oxfors. Journal of Adolescence, 47-55.

Hicks, K., \& Hinck, S. (2007). Concept Analysis of Self-Mutilation. Missouri, USA: Blackwell Publishing Ltd.

Holman, C. H. (1972). A Handbook to Literature. Indianapolis, New York: The Bobbs-Merrill Company.

Jan, A. (2015). Bullying in Elementary Schools: Its Causes and Effects on Students. Journal of Education and Practice, 43-57.

Johnston, J. (2011, April 19). Demi Lovato Interview: Teen Star Opens Up on Bulimia, Cutting Issues. Retrieved from ABC NEWS: www.abcnews.go.com/Entertainment

Jung, C. G. (1997). Visions: Notes of the Seminar Givenin 1930-1934. Princeton: Princeton University Press.

Kolk, B. A., Hopper, J., \& Crozier, J. (2001). Child Abuse in America: Prevalence and Consequences. Journal of Aggresion, Maltreatment, and Trauma, 1-20.

Lee, I.-L. (2010). Self-Destructive Behaviour Among Taiwanese Young People. Glasgow, Scotland, UK: University of Glasgow.

Luna, A. (2016, June 11). 17 Habits of the Self-Destructive Person. Retrieved from LonerWolf: www.lonerwolf.com 
Jurnal DinamikA

Volume 1 No. 2 (2020)

E-ISSN: $2723-1410$

Website: https://jurnal.iainsalatiga.ac.id/index.php/dinamika/index

McDonald, C. (2006). Self-mutilation in adolescents. Journal of School Nursing, 193-200.

Neuman, F. (2017, January 01). Why Do Some People Do Self-Destructive Things? Retrieved from Dr. Neuman's Blog: http://fredricneumanmd.com/blog/

Nock, M. K. (2010). Self-Injury. The Annual Review of Clinical Psychology, 339-363.

Orden, K. V., Witte, T., Cukrowicz, K., Braithwaite, S., Selby, E., \& Joiner, T. (2010). The Interpersonal Theory of Suicide. Psychological Review, 575-600.

Raptou, E. (2017). Literature and Bullying: Teenage and Children Novels on School Bullying Prevention . International Journal of Criminology and Sociology, 183-191.

Ratnatika, G. (2018, October 08). Tren Siswa SMP Sayat Diri Sendiri, Gejala Apa? Retrieved from Watyutink: www.watyutink.com/topik/humaniora/Tren-Siswa-SMP-Sayat-Diri-SendiriGejala-Apa

Rissanen, M.-L., Kylma, J., \& Laukkanen, E. (2011). A Systematic Literature Review: SelfMutilation amongAdolescents as a Phenomenon and Help for it-What Kindof Knowledge is Lacking? Mental Health Nursing, 575-583.

Seixas, S. R., Coelho, J. P., \& Fishcer, G. N. (2013). Bullies, Victims and Bully-Victims Impact on Health Profile. Educação, Sociedade $\mathcal{E}$ Culturas, 53-75.

Sell, S. V., O'Quinn, L., Oliphant, E., Shull, P., Johnston, E., \& Nguyen, C. (2005). Help stop selfinjury. $R N$ 68, 55-58.

Siregar, R. U. (2017). Analysis of Suicide in "The Virgin Suicide" Novel by Jeffrey Eugenides Based on Sociological Perspective. Tangerang Selatan: Universitas Pamulang.

Strong, M. (1998). A Bright Red Scream: Self-mutilation and the Language of Pain. New York City: Viking.

Wellek, R., \& Warren, A. (1949). Theory of Literature. New York: Harcourt, Brace and Company. 
Wolde, Y. S. (2014). A TEMPORARY SOLUTION TO A PERMANENT PROBLEM - how to care for individuals with self-destructive behaviors in open-care. Vaasa, Finland: Novia University of Applied Sciences.

Wood, S. C. (1997). An Investigation of Psychological Distress and Self-Destructive Behavior in Adult Victims of Childhood Sexual Abuse. Allendale, Michigan: Grand Valley States University.

Zhang, Y. (2014). From Self-identification to Self-destruction - A Mirror Image Interpretation of Dorian Gray's Psychic Transformation. Jiangsu, China: Nantong University. 